\title{
The Effectiveness of Hybrid Structure in Overcoming Coastal Abration in Trimulyo, Genuk Subdistrict Semarang City
}

\author{
Domas Kurnia ${ }^{1, *}$, Denny Nugroho ${ }^{2,3}$ \\ ${ }^{1}$ Master Program of Environmental Science, School of Postgraduate Studies, Diponegoro University, Semarang, Indonesia \\ ${ }^{2}$ Department of Oceanography, Faculty of Fisheries dan Marine Science, Diponegoro University, Semarang, Indonesia \\ ${ }^{3}$ Center fo Coastal Disaster Mitigation and Rehabilititation Studies, Diponegoro University, Semarang, Indonesia
}

\begin{abstract}
Trimulyo is one of coastal village in Genuk Subdistrict, Semarang City which now facing serious coastal abrasion. Such a thing has been causing loss of ponds and settlements. One of solution which currently carried is hybrid structure which combining permeable structure to break up the waves and trap sediment. The hybrid structure is designed as agitation dredging, which increase suspended sediment in sea water. The goals of this research were to studying the effectiveness of hybrid structure in hand ling coastal abration and to counting the volume of sedimentation during 20 months as well as rate of sedimentation. To reach the goals, high resolution satellite imagery year 2015 and 2016, scaled stick and sediment trap were applied to the study. Image processing was conducted by using Arc GIS 10.3 software. The effectiveness of hybrid structured was determined by series of field survey of existing condition. Rate of sedimentation measured during before and after hybrid structure built (20 months). The results showed that hybrid structure was effective to reduce coastal abrasion, it proven by a large amount of sediment was trapped behind the structure and coastline was upward along 170 meter since it was built. The volume of sediment during 20 months is $81.500 \mathrm{~m}^{3}$. If it assumed that the rate of sedimentation constantly, monthly rate of sedimentation is $4.075 \mathrm{~m}^{3} /$ month or daily rate is $135,8 \mathrm{~m}^{3} /$ day. The sediment that has formed highly recommended to use as mangrove conservation area in Semarang City.
\end{abstract}

\section{Introduction}

According to Dinas Kelautan dan Perikanan Kota Semarang, Semarang city is one of coastal regency in northern Java Sea that seriously facing coastal degradation called abrasion, land subsidence and water inundation. Due to coastal degradation, there are many impacts material and immaterial damage, for instance loss of ponds, settlements and infrastructures. Trimulyo village is one of the most coastal area that facing such degradations [1].

There were many efforts have done by many institutions, communities and universities. The efforts include the built of hard structure and soft structure that called hybrid structure. Hybrid structure was developed to reduce wave energy, this system was adopt from mangrove ecosystem. Permeable structure was designed to trap the sediments in the structure. In late of 2015, hybrid structure was built in Trimulyo coastal, but the effectiveness of this structure has not been studied.

This research was done to give information to the stakeholder about the effectiveness of hybrid structure to reduce coastal abrasion, counting volume and rate of sedimentation.

\section{Materials and methods}

\subsection{Time and location}

The research was done on January-February 2017 located in Trimulyo village, Sayung Sub District, Semarang city. (Figure 1).

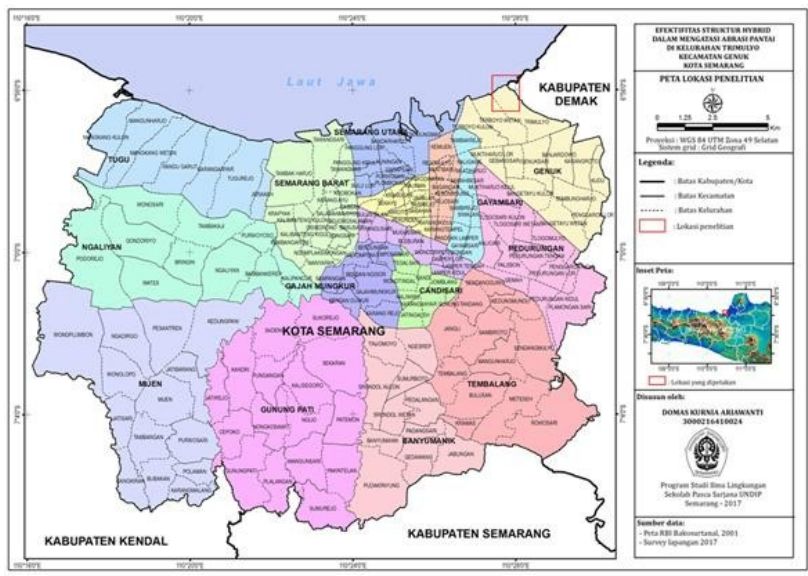

Fig. 1. Map of Research Location 
The material used in this research were primary and secondary data. The primary data were high resolution satellite imagery and sediment data in hybrid structure. The secondary data were bathymetric map of scale 1:25.000 published by Bakosurtanal and tides data.

\subsection{Methods, processing and analyses}

\subsubsection{Image processing, coastline delineation and sediment spreading in hybrid structure}

High resolution satellite imagery was applied to detect the change of sediment before and after hybrid structure built (2015 and 2017). Those high resolution satellite imagery was download from google earth and digitally processing to georeferenced into real coordinate to the earth.

Satellite image composite was done by using visible and invisible bands to mapping objects using fusion techniques in $0.5 \mathrm{~m}$ colour spatial resolution, filtering also applied to colour enhancement. This applied to simplify objects identification for visual interpretation. The methods applied was linear contrast enhancement for reduce spectral and visual distortion of satellite imagery.

\subsubsection{Costline delineation and Sediment spreading}

Coastline delineation anf sediment spreading was done using on screen digitations on Arc GIS 10.3 software. Those objects was clearly can be determined by visual interpretation on high resolution satellite imagery.

\subsubsection{Accuration test and reinterpretation}

Accuration test performed to validate result of interpteration and ground check. Accuration test done using the matching of interpretation and real condition by ground checking (Short in Sutanto,1992).

Accuration $=$ True interpretation
Total sampel.........(1)

\subsubsection{Sediment spreading counting, volume and rate of sedimentation}

Spread of sediment was calculated using Arc GIS 10.3. This methods was developed due to matching of visual interpretation and ground checking. The volume of sedimentation was calculated by data of length, width and the depth of sediment trapped. Systematically the formulas as follow:

$$
\text { Volume }=\text { length } \mathrm{x} \text { width } \mathrm{x} \text { depth.....(2) }
$$

Depth of sedimentation was calculated by bathimetric data and scaled stick that has been placed in trapped sediment. Meanwhile the rate of sedimentation calculated by the accumulation of sediment during 20 months. It was assumed that the rate of sedimentation is constant during all months. Monthly rate of sedimentation formulas are as follows: $\mathrm{v}=$ Volume $/ 20$ month

$\mathrm{v}=$ monthly rate of sedimentation $\left(\mathrm{m}^{3} / \mathrm{month}\right)$

\subsubsection{Sampling sediment methods}

Sediment sample was done once in three stations. Sample was taken using eckman grab (500 gram), stored in labelled plastic and analysed in laboratorium. Sediment analyses was using sediment fraction and wet gravel, using pipet texture analyses Rifardi, stated [2]

Dyer, Davis subscribed that Based on Wenworth scale, sediment s classify by fraction size, clay, silt, gravel, pebble, cobble dang boulder. That scale refers to standart size of fraction in micron to millimeter with continuous spectrum [3] [4].

\subsubsection{Hidro oseanography}

The oceanographic factors take a very important role in the sedimentation in the coastal, namely tide and sea current. Those two parameters were very close related to the dynamic of coastal area. Those factors were analyses by secondary data.

\section{Results and discussion}

\subsection{Image processing, digitations and accuration test}

High resolution satellite imagery was downloaded in JPG Format. Series of processing was done using Arc GIS 10.3 with the regional spatial plannnig (Rencana Tata Ruang Wilayah- RTRW) Semarang City as basemap. Geometric correction was done using georeferenced tool in Arc Map 10.3

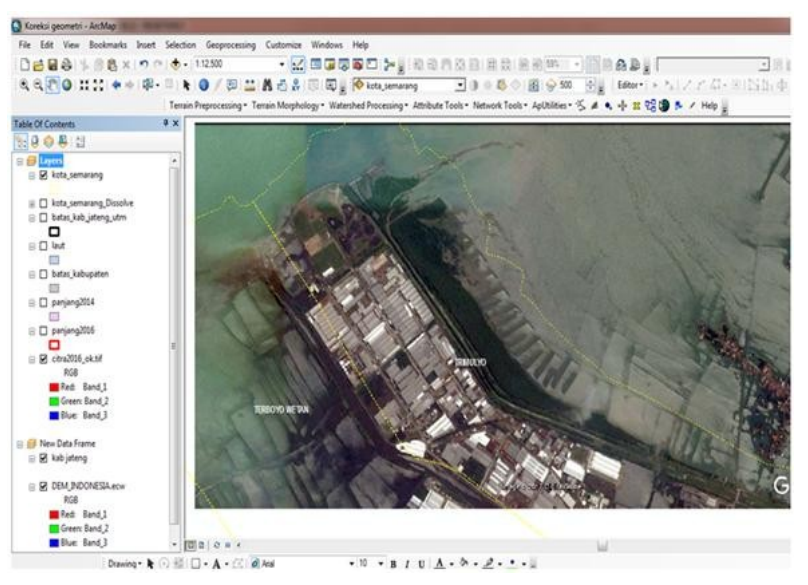

Fig. 2. Geometric image processing

Based on digital processing, trapped sediment in hybrid structure was clearly seen by visual interpretation as figure 3 below: 


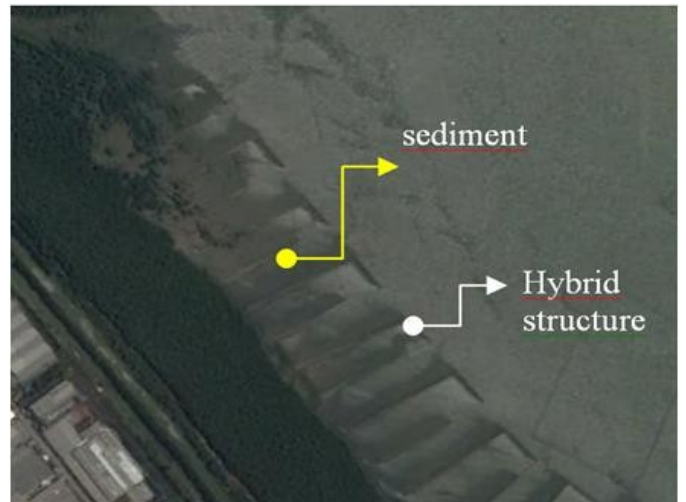

Fig.3. Trapped sediment in hybrid structure identified using high resolution satellite imagery.

Daruati subscribed that accuration test was done to validate visual interpretation using satellite imagery and real condition by field survey. Accuration test was done in 10 location within the hybrid structure. Based on accuration test, the accuracy of interpretation was 90 percent, because there was one missing objects between interpretation and field survey. Based on USGS criteria, this accuration can be use because more than $85 \%$ [5].

\subsection{The Effectiveness of hybrid stucture}

The effectiveness of hybrid structure was analysed descriptively by series of field survey. Based on existing condition, hybrid structure is effective in redusing coastal abration, It is proof by the trapped sediment in the structure. Field documentation of the effectiveness of this structure as figure 4 below.

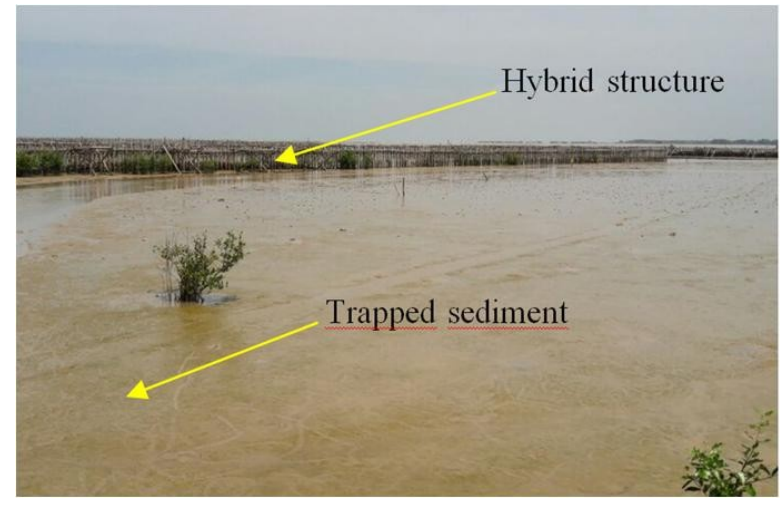

Fig.4. Existing condition in hybrid structure

Based on series of field survey, hybrid structure is very effective to trapped sediment and recover coastal abration. Since it was built 20 months ago there is much sediment trapped within the structure. The sedimentation occurred as the impact of the design of permeable hybrid structure that allows sediment to entering the structure and trapped in it.

Hybrid structure can trap the sediment because permeable structure that not reflecting the wave but deflect the wave energy. The energy of long shore current and wave will and all sediment taken will be trapped. This structure is very effective to recover losses abration area. The design of hybrid structure has been considering the wave and long shore current, so sediment easily trapped in the structure.

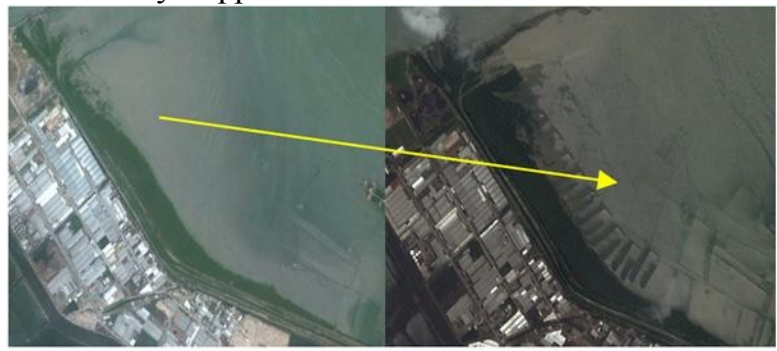

Fig. 5. Citra satellite 27 Februari 2015 (before Hybrid structure) Citra satellite 13 September 2016 (before Hybrid structure)

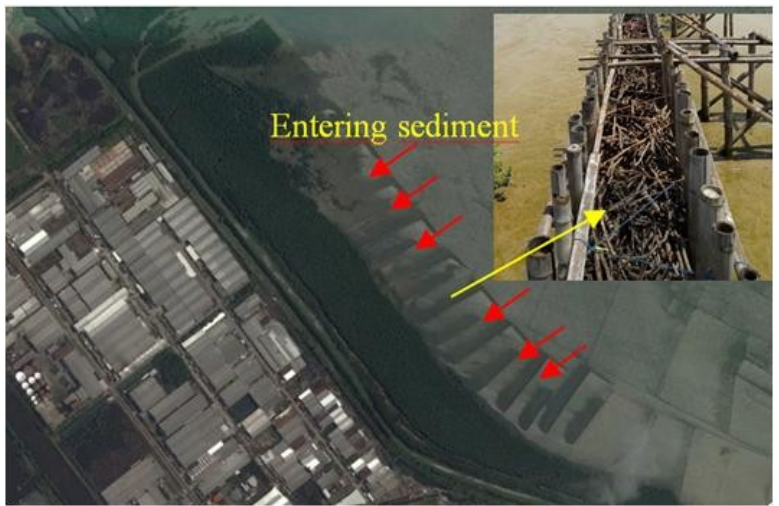

Fig. 6. Hybrid structure design to trapped sediment.

\subsection{Calculation of volume and rate of sedimentation}

Based on delineation and field survey, there were 81.500 $\mathrm{m}^{3}$ sediment was trapped in the structure within 20 months. If it assumed that the rate of sedimentation is constant, the rate of sedimentation as $4.075 \mathrm{~m}^{3} /$ month or $135.8 \mathrm{~m}^{3} /$ day. The map of sediment within the hybrid structure as follows.

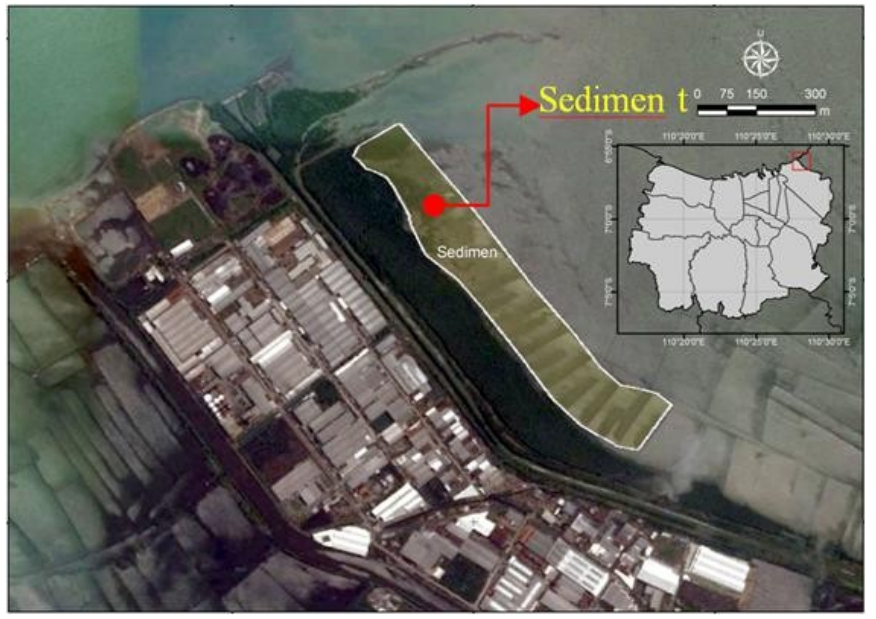

Fig. 7. Map of Sediment Distribution

As seen on figure 7, sediment distribution trapped all in hybrid structure. It proved that hybrid structure was very effective to recover coastal abration. 


\subsection{Sediment analyses}

Trapped sediment in the hybrid structure visually is mud. For more information, the sediment was analysed in laboratory. Based on laboratory analyses (figure 7), sediment composition were $90,9 \%$ silt, mud $3 \%$, fine sand $5,6 \%$ dan coarse sand $0,5 \%$. Those result showed that silt is the most material formed the sediment in hybrid structure.

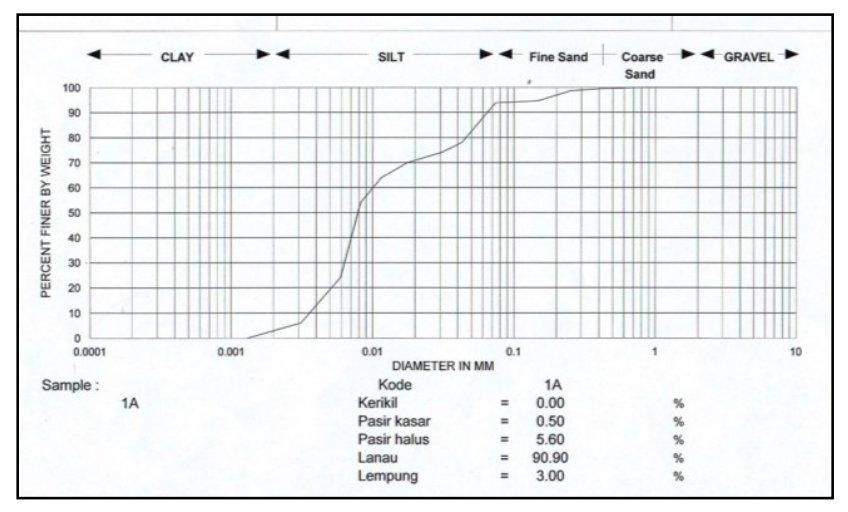

Fig. 7. Laboratory analyses of sediment

Bowles described that lanau is fine-grained soils that are smaller than $0.074 \mathrm{~mm}$ (No. 2000. Silt and clays mostly found in the coastal and estuary [6].

\subsection{Oceanographic parameters}

\subsubsection{Sea current}

Ocean currents is a horizontal mass of seawater caused by the wind, sea waves and tides. Based on Fisheries Services of Semarang City, the current pattern in May 2015 - April 2016 the maximum speed of long shore current was $0.064 \mathrm{~m} / \mathrm{s}$ and the minimum speed was $0.008 \mathrm{~m} / \mathrm{s}$ that moving toward the west of Semarang. The highest current occurred in December with $0.19 \mathrm{~m} / \mathrm{s}$ in speed and the minimum speed occurred in August 2016 with speed $0.008 \mathrm{~m} / \mathrm{s}$. The average of long song current speed was $0.1 \mathrm{~m} / \mathrm{s}$ [1].

\subsubsection{Tides}

Tides are the rise and fall of sea levels caused by the combined effects of the gravitational forces exerted by the Moon and the Sun and the rotation of Earth. The times and amplitude of tides at any given locale are influenced by the alignment of the Sun and Moon, by the pattern of tides in the deep ocean, by the amphidromic systems of the oceans, and the shape of the coastline and near-shore bathymetry. While tides are usually the largest source of short-term sea-level fluctuations, sea levels are also subject to forces such as wind and barometric pressure changes, resulting in storm surges, especially in shallow seas and near coasts. Hakim, et al. described that tidal type in Semarang City was tend to diurnal [7].

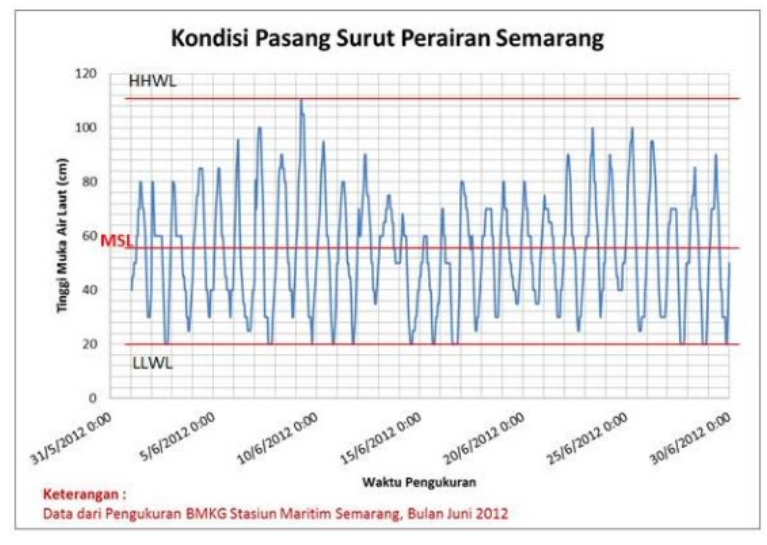

Fig. 8. Tidal pattern in Semarang City between January to August 2017

\subsubsection{Wave}

Danial subscibed that waves are the forward movement of the ocean's water due to the oscillation of water particles by the frictional drag of wind over the water's surface.[8]

Waves is one of the parameters of oceanography very affect the coast.Triatmodjo stated that can give rise to a wave of energy to form the coast, give rise to the current, well as result in energy which works on the the coast .Three factors that determine the characteristics of a wave that is fueled by the wind i.e. (1) blowing duration of the wind, (2) wind speed and ( 3 ) fetch ( the distance traveled by the wind from the direction of stirring up a wave or the region of the generation of waves. [9]

According to Hakim et. Al. the height of waves in Semarang relatively small, ranged from $0,35 \mathrm{~m}$ up to 0,89 $\mathrm{m}$ with the period between 3.5 seconds to 5.8 seconds. This indicates that a wave that formed in waters Semarang can be described is strongly influenced by a wind occurring [7].

Oceanographic factors has been considered in the process of designing hybrid structure. There were many inlets in hybrid structure to trapped sediment. Based on field observation, those structure was very effective to trapped the sediment along hybrid structure. It proven by the sediment formed and coastline forward $170 \mathrm{~m}$ since it was built.

\section{Conclusion}

Based on this research, the conclusions are:

a. The hybrid structure in Trimulyo village, Genuk Sub district, Semarang City is very effective in overcoming coastal abration, it proved by the sediment formed in the structure and the coastline forward $170 \mathrm{~m}$ since it was built.

b. The volume sedimentation during 20 month was $81.500 \mathrm{~m}^{3}$. If it assumed that the rate of sedimentation were constant during all months, the monthly rate of sedimentation is $4.075 \mathrm{~m}^{3} /$ month or $135,8 \mathrm{~m}^{3} /$ day. 
c. Formed sediment in hybrid structure highly recommended for mangrove conservation in Semarang City.

\section{References}

1. Dinas Kelautan dan Perikanan Kota Semarang, Kajian Penanganan Pesisir Kota Semarang. (DKP Kota Semarang, 2016)

2. Rifardi, Ukuran Butir Sedimen Perairan Pantai Dumai Selat Rupat Bagian Timur Sumatera. (Jurnal Ilmu Lingkungan Universitas Riau. ISSN 1978-5283, 2008)

3. K.R. Dyer, Coastal and Estuarine Sedimen Dynamic. (New York: John Wiley and Sons Ltd, 1986)

4. Davis, R.A.Jr, An Introduction to Sedimentology and Stratigraphy Depositional System. (New York: Precite Hall-Englewood Cliff, 1993)
5. D. Daruati, Penggunaan Citra Satellite Landsat 7ETM+ Untuk Kajian Penggunaan Lahan DAS Cimanuk.LIMNOTEK, XV,40-50, (2008)

6. Bowles, E. Joseph, Sifat-sifat Fisis dan Geoteknis Tanah ( Erlangga,Jakarta, 1991)

7. Hakim, A. Buddin, Suharyanto, Wahyu Krisna Hidayat, Buletin Oseanografi Marina (Juli 2013.2, $81-93,2013$ )

8. M. Danial, Rekayasa Pantai. (Alfabeta, Bandung, 320, 2008)

9. Triatmodjo, Bambang, Hidrologi Terapan. (Beta Offset, Yogyakarta, 2008)

10. W. Mahardi, Kajian Efektivitas Metode Struktur Alat Pemecah Ombak (APO) dan Hybrid Engineering (HE) sebagai studi pengembangan konsep rehabilitasi pantai di Kabupaten Demak. (Thesis: Universitas Indonesia, 2014)

11. I Alifdini, D N Sugianto, Y O Andrawina and A B Widodo, Bali. Indonesia. IOP Conference Series: Earth and Environmental Science. 55 (2017) 